\title{
Causes of Transfer of Neonates (Born after $\geq 34$ Weeks of Gestation) to the Neonatal Intensive Care Unit Owing to Respiratory Distress and their Clinical Features
}

\author{
Yu Jin Jung \\ Department of Pediatrics, Kosin University Gospel Hospital, Kosin University College of Medicine, Busan, Korea
}

\section{ABSTRACT}

Purpose: Respiratory morbidity is the most common problem among neonates admitted to neonatal intensive care units. Therefore, the aim of this study was to make a differential diagnosis between transient tachypnea of the newborn (TTN), respiratory distress syndrome (RDS), and pneumonia through comparison of clinical features and test results.

Methods: This retrospective study was conducted in 86 infants with TTN, RDS, or pneumonia. These were infants who had respiratory distress, were born after $\geq 34$ weeks of gestation, and transferred to the neonatal intensive care unit of Kosin University Gospel Hospital between June 1, 2011 and June 30, 2016.

Results: The numbers (percentage) of infants with TTN, RDS, and pneumonia were 51 (59.3\%), 20 (23.3\%), and 15(17.4\%), respectively. Late-preterm and early-term newborns accounted for $65.1 \%$ of the infants. Tachypnea was observed in $74.4 \%$ of the neonates. The median age at admission was 4 hours ( 0 to 116) after birth. The infants with RDS had significantly lower birth weights, $\mathrm{pH}$ levels, base excess and oxygen saturation levels at admission, longer duration of total ventilator therapy, and hospital stay than those in the other two groups. The infants with pneumonia showed significantly high initial highsensitivity C-reactive protein levels and significant chest radiographic findings.

Conclusion: Early differential diagnosis for TTN, RDS, and pneumonia is challenging because they show similar respiratory symptoms at an early stage. Clinical features and test results can be used to determine the etiology of respiratory distress and early antibiotic treatment.

Key Words: Etiology, Infant, Respiration disorders

서론

신생아의 호흡곤란은 신생아의 $7 \%$ 에서 ${ }^{1)}$ 나타나는 흔한 증상이며, 신생아중환자실로 입원하 는 가장 흔한 원인이 된다 ${ }^{2,3)}$. 신생아 호흡곤란을 보이는 질환으로는 신생아 일과성 빠른호흡, 신 생아 호흡곤란 증후군, 태변 흡인 증후군 등이 흔한 편이며 그 외에 감염, 이행 지연, 폐동맥 고혈
Received: 7 December 2017

Revised: 3 May 2018

Accepted: 18 May 2018

Correspondence to: Yu Jin Jung

Department of Pediatrics, Kosin University Gospel Hospital, Kosin University College of Medicine, 262 Gamcheon-ro, Seo-gu, Busan 49267, Korea

Tel: +82-51-990-3336

Fax: +82-50-4392-7893

E-mail: hasaohjung@hanmail.net

Copyright(c)

By Korean Society of Neonatology.

All right reserved.

This is an Open-Access article distributed under the terms of the Creative Commons Attribution Non-Commercial License (http://creativecommons.org/licenses/ by-nc/4.0), which permits unrestricted non-commercial use, distribution, and reproduction in any medium, provided the original work is properly cited. 
압, 기흥 등이 있으며 비호흡기계 원인으로는 빈혈, 적혈구 증가증, 선천성 심질환, 산모의 약물 복용, 신경학적 혹은 대사 이상, 상기도 폐쇄 등이 있을 수 있다 ${ }^{4)}$ 본 연구에서 저자는 호흡곤란으로 전원 된 환자 중에서 태변 착색이 없었던 즉, 태변 흡인 증후군이 아닌 환자 들이 전원 되었을 때, 신생아 일과성 빠른호흡, 신생아 호흡곤란 증 후군, 선천성 폐렴이 비슷한 호흡 증상으로 시작하기 때문에 임상 양 상 및 검사 결과 등을 비교하여 조금 더 빠르게 진단하고 적절한 처 치를 할 수 있는 특이점이 있는지 알아보고자 연구를 시행하였다.

\section{대상 및 방법}

\section{1. 대상}

2011년 6월부터 2016년 6월까지 분만 전과 분만 중 태변 배출이 없는 신생아들을 대상으로 출생 후 호흡곤란 증상으로 분만 병원 신 생아실에서 고신대학교 복음병원 신생아집중치료실로 전원 되어 입 원한 재태 기간 34주 이상인 신생아 90명을 대상으로 하였다. 태변 착색이나 태변 및 양수 흡입이 있는 환자는 태변 및 양수 흡입 증후 군으로 일차적 분류가 가능할 수 있으므로 선정 대상에서 제외하였 고 주요 선천성 기형도 배제하였다. 그리고 호흡곤란의 원인으로 폐 병변을 기준으로 비교하고자 전원 이후 경련이 관찰된 4 명의 환자도 제외되었다. 따라서 호흡곤란의 주 원인으로 폐질환을 보인 86명 환 자들을 대상으로 후향적인 의무기록지를 조사하였다. 이 연구는 본 원 임상연구윤리위원회에서 승인을 받았다(IRB No. 2016-12-005).

\section{2. 방법}

호흡 증상으로는 호흡수가 1 분당 60 회 이상의 빠른호흡, 호흡근 당김 증상, 끙끙거림, 청색증, 그리고 호흡이 20초 이상 정지하거나 서맥 및 청색증이 동반된 호흡 정지와 같은 무호흡 증상이 관찰된 경 우로 하였다. 환자들에 대해 재태 기간, 출생 체중, 성별, 아프가 점 수, 분만 방법, 산모의 나이, 입원할 때 출생 후 나이(시간), 입원 기 간, 입원할 때 시행한 동맥혈 가스분석검사, 혈당, 고감도 C-반응단 백질(high-sensitivity C-reactive protein, hsCRP), 혈색소, 백혈구, 혈 소판, 혈액배양 검사, 흥부 방사선 검사, 인공호흡기 치료 여부, 수유 시기 및 입원 후 첫 3 일간의 소변량 등을 조사하였다. 인공호흡기 치 료는 침습적인 기계적 환기 요법과 비침습적인 지속적 양압 환기 요 법을 구분하여 포함시켰다. 신생아 일과성 빠른호흡(I)은 흥부 방사 선 사진에서 과팽창된 상태이거나 양측 폐문부의 햇살 모양 및 폐엽 간의 균열 부종이 관찰되거나 빠른호흡을 일으킬 만한 다른 원인이 없는 경우로 판단될 때에 진단하였다 ${ }^{3,5)}$. 신생아 호흡곤란 증후군(II) 은 흥부 방사선 검사에서 공기 기관지 조영 혹은 망상과립의 유리 혼 탁이 하나 이상 관찰되면서 호흡곤란 증상을 보일 때에 정의하였다 ${ }^{3,5)}$. 폐렴(III)은 호흡곤란이 신생아 패혈증의 한 증상으로 판단되어
혈액, 뇌척수액 배양 검사를 시행하여 항생제를 사용하고 흥부 방사 선 검사에서 반점형 혼탁 및 폐 실질의 침윤이 있는 경우에 분류하였 다 ${ }^{3,5)}$.

\section{3. 통계학적 분석}

조사 자료들을 Microsoft Excel 2007 (Microsoft, San Francisco, CA, USA)에 입력하고 PASW statistics version 19 (IBM Co., Armonk, $\mathrm{NY}, \mathrm{USA}$ )를 이용하여 연속변수들은 mean \pm standard deviation 또는 정규분포를 따르지 않을 경우에는 median (range)로 표시하였다. 연속변수들은 분산분석(analysis of variance, ANOVA)이나 KruskalWallis 분석을 시행하였고, 범주형 변수들은 카이제곱검정을 이용하 였다. $P$ 값이 0.05 미만일 때 통계적으로 유의하다고 판단하였다.

결과

\section{1. 환자의 특징}

연구 대상 86명 중 원인별로 신생아 일과성 빠른호흡(I), 신생아 호흡곤란 증후군(II), 그리고 폐렴(III)이 각각 51명(59.3\%), 20명 (23.3\%), 15명(17.4\%) 이었다(Figure 1). 성별로는 남아가 54명(62.8 $\%)$ 이고 여아가 32 명이었다. 평균 재태 기간은 $38.0 \pm 1.7$ 주였고, 세 군 간의 재태 기간은 차이가 없었다. 전체 환자 중 후기 조산아(3436 주)와 조기 만삭아(37-38주)가 31.4\% (27/86)와 33.7\% (29/86)를 차지하였다. 평균 출생 체중은 $3,233 \pm 474 \mathrm{~g}$ 이었으며, I군과 II군에서


보다 의미 있게 적었다. 전원 되어 입원할 때 환자들의 중간 나이가 출생 후 4시간이었고, 출생 후 1 시간 이내가 가장 일찍 전원 되어 입 원한 경우였다. 가장 늦은 환자가 출생 후 116 시간에 입원 한 경우였 다. 대상 환자 중 제왕절개술로 출생한 환자는 53명(61.6\%)이었다. 그리고 대상 환자들의 산모 평균 나이는 $32.7 \pm 4.9$ 세였고 세 군 간의 차이는 없었다(Table 1).

재태 기간 37 주 이상 만삭아를 기준으로 세 군 간의 차지하는 비 율을 비교하였을 때, 폐렴(III) 환자에서 13명(86.7\%, 13/15)으로 가 장 많았고, II군에서 13 명 $(65 \%, 13 / 20)$, I군에서 33 명(64.7\%)으로 비

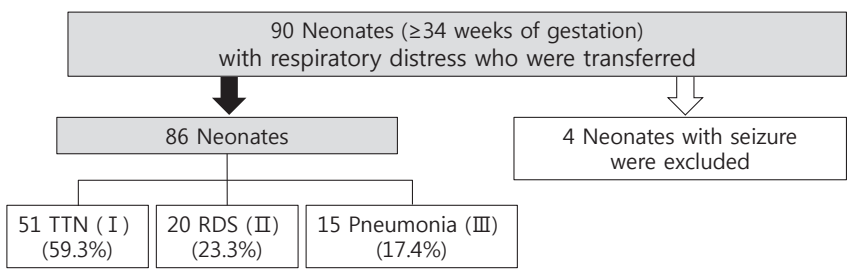

Figure 1. Flowchart of the infants. Abbreviations: TTN, transient tachypnea of the newborn; RDS, respiratory distress syndrome. 
Table 1. Characteristics of Groups

\begin{tabular}{|c|c|c|c|c|}
\hline Characteristic & $\operatorname{TTN}(\mathrm{I})(\mathrm{n}=51)$ & RDS (II) (n=20) & Pneumonia (III) $(n=15)$ & Total $(\mathrm{n}=\mathbf{8 6})$ \\
\hline Birth weight (g) & $3,191.2 \pm 458.9^{*}$ & $3,118.5 \pm 489.3^{*}$ & $3,528.3 \pm 408.8$ & $3,233.1 \pm 473.7$ \\
\hline GA (wk) & $37.9 \pm 1.6$ & $37.9 \pm 1.7$ & $38.5 \pm 2.1$ & $38.0 \pm 1.7$ \\
\hline 37-38 week's gestation & $15(29.4)$ & $7(35)$ & $7(46.7)$ & $29(33.7)$ \\
\hline $39-40$ week's gestation & $12(23.5)$ & $4(20)$ & $1(6.7)$ & $17(19.8)$ \\
\hline Age of infants at admission (hr) & $4(1-116)$ & $3.5(1-11)$ & $5(0-21)$ & $4(0-116)$ \\
\hline Age of mothers & $31.7 \pm 5.0$ & $33.9 \pm 3.8$ & $34.5 \pm 5.5$ & $32.7 \pm 4.9$ \\
\hline Male sex & $35(68.6)$ & $12(60)$ & $7(46.7)$ & $54(62.8)$ \\
\hline C-section delivery & $35(68.6)$ & $10(50)$ & $8(53.3)$ & $53(61.6)$ \\
\hline
\end{tabular}

Values are expressed as mean \pm standard deviation, number (\%), or median (range).

${ }^{*} P<0.05$ compared to III.

Abbreviations: TTN, transient tachypnea of the newborn; RDS, respiratory distress syndrome; GA, gestational age.

Table 2. Respiratory Features of Infants at Admission and after Birth

\begin{tabular}{|c|c|c|c|c|}
\hline Characteristic & $\operatorname{TTN}(\mathrm{I})(\mathrm{n}=51)$ & $\operatorname{RDS}(\mathrm{II})(\mathrm{n}=20)$ & Pneumonia (III) $(n=15)$ & Total $(n=86)$ \\
\hline RR at admission (breaths/min) & $69.0 \pm 15.7$ & $65.0 \pm 14.8$ & $70.4 \pm 15.7$ & $68.3 \pm 15.5$ \\
\hline $\mathrm{RR} \geq 60$ breaths $/ \mathrm{min}$ at admission & $41(80.4)$ & $12(60)$ & $11(73.3)$ & $64(74.4)$ \\
\hline Within first 72 hours of life & 38 & 13 & 11 & 62 \\
\hline Between $72-168$ hours of age & 12 & 4 & 3 & 19 \\
\hline Cyanosis at admission & $8(15.7)$ & $5(25)$ & $2(13.3)$ & $15(17.4)$ \\
\hline $\mathrm{pH}$ & $7.33 \pm 0.08$ & $7.27 \pm 0.10^{*}$ & $7.34 \pm 0.06$ & $7.32 \pm 0.08$ \\
\hline $\mathrm{pCO}_{2}$ & $42.0 \pm 12.8$ & $48.4 \pm 12.7$ & $42.7 \pm 7.9$ & $43.6 \pm 12.2$ \\
\hline $\mathrm{pO}_{2}$ & $62.5 \pm 24.3$ & $57.4 \pm 25.9$ & $63.5 \pm 22.8$ & $61.5 \pm 24.3$ \\
\hline Total ventilator duration (day) & $0.86(0-9)$ & $8.5(0-19)^{*, \dagger}$ & $3.5(0-9)$ & $1.79(0-19)$ \\
\hline Invasive ventilator (day) & $0.12(0-4)$ & $6.2(0-19)^{*, \dagger}$ & $1.0(0-6)$ & $0.69(0-19)$ \\
\hline No. of infants & 2 & 16 & 4 & 22 \\
\hline Non-invasive ventilator (day) & $0.86(0-9)$ & $0.75(0-8)$ & $1.4(0-7)$ & $0.59(0-9)$ \\
\hline No. of infants & 16 & 9 & 7 & 32 \\
\hline Abnormal CXR & $17(33.3)$ & $20(100)$ & $12(80)$ & $49(57.0)$ \\
\hline
\end{tabular}

Values are expressed as mean \pm standard deviation, number (\%), or median (range).

* $P<0.05$ compared to I; ${ }^{\dagger} P<0.05$ compared to III.

Abbreviations: TTN, transient tachypnea of the newborn; RDS, respiratory distress syndrome; RR, respiratory rates; CXR, chest X-ray.

슷하였다. 성별을 기준으로 비교하였을 때, I군과 II군에서 남아가 더 많았지만 III군은 여아가 더 많이 차지하였다. 또한, 제왕절개술 이 II군과 III군에서는 같거나 비슷하였으나, I군에서는 더 많았다 (Table 1).

\section{2. 세 군 간의 임상적 특징 비교}

호흡곤란 증상 중에 입원 당시 64명(74.4\%)에서 호흡수가 분당 60 회 이상인 빠른호흡 증상을 보였다. 그리고 78명(90.7\%)이 출생 후 12 시간 이내에 호흡곤란 증상을 보여 전원 되었으며 3명을 제외하 고는 출생 후 24 시간 이내에 증상을 보여 전원 되었다(96.5\%). 24시 
Table 3. Clinical Factors during Admission

\begin{tabular}{lccc}
\hline Factor & TTN $(\mathrm{I})(\mathrm{n}=51)$ & RDS (II) (n=20) & Pneumonia (III) (n=15) \\
\hline Duration of hospital stay (day) & $9.0 \pm 4.0$ & $22.4 \pm 28.6^{* *^{\dagger}}$ & $10.8 \pm 3.8$ \\
Blood sugar test $(\mathrm{mg} / \mathrm{dL})$ & $72.5 \pm 19.4$ & $81.4 \pm 21.2$ & $72.3 \pm 20.9$ \\
U/O on HD1 (cc/hr/kg) & $1.8 \pm 1.1$ & $1.3 \pm 0.9^{\dagger}$ & $2.3 \pm 1.5$ \\
U/O on HD2 (cc/hr/kg) & $2.6 \pm 0.7$ & $2.4 \pm 1.1$ & $2.3 \pm 0.7$ \\
U/O on HD3 (cc/hr/kg) & $2.4 \pm 0.7$ & $2.5 \pm 1.0$ & $2.9 \pm 0.7$ \\
Age at feeding start (day) & $1.2 \pm 0.4$ & $3.6 \pm 3.8^{* *^{\dagger}}$ & $1.5 \pm 1.6$ \\
Age at first full $(100 \mathrm{cc} / \mathrm{kg} /$ day) feeding (day) & $5.4 \pm 1.7$ & $12.1 \pm 6.1^{* \dagger}$ & $6.4 \pm 3.0$ \\
Initial hsCRP $(\mathrm{mg} / \mathrm{dL})$ & $0.1 \pm 0.1$ & $0.2 \pm 0.5^{\dagger}$ & $1.2 \pm 1.9^{*}$ \\
Maximal hsCRP $(\mathrm{mg} / \mathrm{dL})$ & $0.2 \pm 0.2$ & $1.8 \pm 2.0^{*}$ & $1.8 \pm 1.8^{*}$ \\
Hemoglobin $(\mathrm{g} / \mathrm{dL})$ & $16.1 \pm 2.3$ & $16.1 \pm 1.7$ & $16.5 \pm 2.3$ \\
WBC $\left(1 \times 1,000 \mathrm{~mm}^{3}\right)$ & $18.4 \pm 4.4$ & $20.0 \pm 6.6$ & $19.2 \pm 10.9$ \\
PLT $\left(1 \times 1,000 \mathrm{~mm}^{3}\right)$ & $251.9 \pm 54.9$ & $235.8 \pm 45.6$ & $240.5 \pm 71.8$
\end{tabular}

Values are expressed as mean \pm standard deviation.

${ }^{*} P<0.05$ compared to $\mathrm{I} ;{ }^{\dagger} P<0.05$ compared to III.

Abbreviations: TTN, transient tachypnea of the newborn; RDS, respiratory distress syndrome; U/O, urine output; HD, hospital day; hsCRP, highsensitivity C-reactive protein; WBC, white blood cell; PLT, platelet.

간 이후에 증상이 나타나서 전원 온 3명은 모두 신생아 일과성 빠른 호흡 환자였다. 이러한 빠른호흡 증상은 출생 후 72 시간 이내에 호 전된 환자가 62 명(72.1\%)이었고 출생 후 7일 이내에 5명을 제외한 모든 환자에서 호전되었다. 그리고 평균 57.5土74.2시간 이내에 좋 아지는 결과를 보였다. 무호흡 증상은 I군에 비해 II군에서 유의하게 관찰되었고, 청색증은 15 명(17.4\%)에서 관찰되었다(Table 2).

호흡곤란으로 전원 된 환자들의 평균 입원 기간은 $12.4 \pm 15.0$ 일

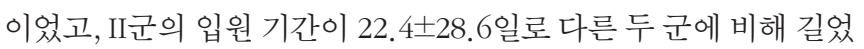
다. 첫 수유가 시작되는 평균 나이가 출생 후 $1.8 \pm 2.2$ 일, $100 \mathrm{cc} / \mathrm{kg} /$

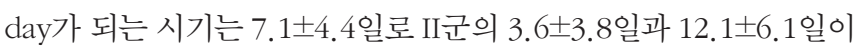
다른 두 군에 비해 의미 있게 늦었다. 하루에 배출되는 소변량은 입 원 첫날에만 II군에서 의미 있게 적었지만, 그 외에는 차이가 없었다 (Table 2). 입원 당시 첫 hsCRP 수치와 입원 기간 중 최대 hsCRP 수 치는 신생아 일과성 빠른호흡군에서만 정상 범위 안에 있었다(정상 범위 $\leq 0.75 \mathrm{mg} / \mathrm{dL})$.

입원 시 신생아 호흡곤란군(II)에서 $\mathrm{pH}$ 가 $7.3 \pm 0.1$, 산소포화도 가 $86.9 \% \pm 15.7 \%$ 로 I군에 비해 의미 있게 낮았으며, base excess가 $-5.3 \pm 3.0$ 으로 III군에 비해서도 낮게 관찰되었다. 흉부 방사선 검사 에서는 신생아 호흡곤란 환자에서 모두 이상 소견을 확인할 수 있었 고, I군에서는 17 명, III군에서는 12 명에서 관찰되었다(Table 3). 호 흡곤란이 지속되는 경우 침습적이거나 비침습적 기계 환기를 시행 하게 되는데 둘 중 하나 이상의 기계 환기 치료를 필요했던 환자는 42 명(48.8\%)이었다. 신생아 호흡곤란 증후군에서 총 기계 환기 기 간이 $8.8 \pm 6.1$ 일로 다른 두 군보다 길었으며 침습적 기계 환기 기간 도 6.7 \pm 5.9일로 더 길었다(Table 2).

\section{고찰}

신생아에서 호흡곤란 증상을 보이는 질환 중에서 신생아 일과성 빠른호흡과 신생아 호흡곤란 증후군 그리고 폐렴은 초기 증상 발현 이 유사할 수 있어 감별이 필요하다. 그래서 본 연구를 통해 호흡곤 란을 일으키는 세 가지 원인에 따른 임상적 특징의 차이들을 알아보 고자 하였다. 그러므로 양수가 태변에 착색 된 채로 태어난 신생아는 태변 흡인 증후군의 원인이 되므로 선별 기준에서 제외되었고 34 주 미만에서 신생아 호흡곤란 증후군의 비율이 높아지므로 ${ }^{6}$ 재태 기간 을 34주 이상으로 제한하였다. 그리고 호흡곤란을 일으키는 원인에 는 호흡기 문제 혹은 호흡기 아닌 문제로 나눌 수 있기에 ${ }^{7)}$ 선별 과정 에서 비호흡기계 원인은 제외하여 폐질환에 국한된 호흡곤란에서 특징의 차이를 알아보고자 하였다.

본 연구에서 신생아 일과성 빠른호흡이 $59.3 \%$ 로 가장 많았고 다 음으로 신생아 호흡곤란 증후군, 그리고 폐렴이 각각 $23.3 \%, 17.4 \%$ 를 차지하여 재태 기간 34-40주 신생아에서는 신생아 일과성 빠른 호흡의 발생률이 가장 높음을 Hermansen와 $\operatorname{Lorah}^{4)}$ 의 연구와 같이 확인할 수 있었다. 재태 기간은 세 군 간에 차이가 없었으나, 전체 환자 중에서 37-38주에 태어난 조기 만삭아가 $33.7 \%$ 로 가장 많은 비율을 차지하였고 후기 미숙아가 $31.4 \%$ 였다. 이는 조기 만삭아가 39-41주에 태어난 만삭아처럼 건강해 보일 수 있지만, 아직 생리학 적으로 미성숙해 있음을 ${ }^{8)}$ 본 연구의 호흡기 질환 발생을 통해서 확 인할 수 있었다. 폐렴은 40주를 초과한 신생아에 많음을 알 수 있었 다. 신생아 호흡곤란 증후군와 신생아 일과성 빠른호흡 환자들이 폐 렴 환자들에 비해 출생 체중이 적은 것으로 보아 출생 체중이 표면 활성제의 생성 및 분비의 부족 뿐 ${ }^{(4)}$ 아니라 태아의 폐액 제거에도 영 
향을 주는 것으로 여겨진다. 제왕절개술을 통해 출생한 신생아에서 신생아의 호흡곤란 및 신생아중환자실 입원율이 높은 것으로 밝혀 졌다 ${ }^{9,10)}$. 그리고 한 연구에 따르면 제왕절개 분만이 질 분만 보다 신 생아 일과성 빠른호흡의 위험이 약 2.8 배 더 높다고 한다 ${ }^{11}$. 본 연구 에서도 세 군 간의 차이는 보이지 않았지만, 전체 환자에서 제왕절개 술 출생이 $61.6 \%$ 로 더 많았고, 특히 신생아 일과성 빠른호흡과 폐렴 환자에서 제왕절개술인 경우가 더 많았다. 최근 임산부의 고령화와 다태 임신 등으로 제왕절개술의 증가 추세를 고려할 때에 신생아 일 과성 빠른호흡과 같은 호흡기 질환의 발생률이 늘어날 수 있을 것으 로 생각된다.

신생아 일과성 빠른호흡은 신생아 호흡곤란의 가장 흔한 원인으 로 출생 직후 태아의 폐포액 제거가 잘 이루어지지 않아 나타나며, 대부분 출생 직후나 2 시간 이내에 증상이 나타나고 ${ }^{12)} 24-72$ 시간 정 도 호흡곤란 증상이 지속되다가 자연 호전되어 기계 환기가 필요 없 는 경우가 많다 ${ }^{13)}$. 선천성 폐렴은 원인균이 태반을 통해 태아로 오면 서 생기게 되는데, 첫 48 시간에서 일주일 이내에 나타난다 ${ }^{14)}$. 그러므 로 호흡곤란 증상은 대부분 생후 며칠 이내에 발생하는 가장 흔한 증 상으로 ${ }^{3)}$ 본 연구에서도 전원 된 환자들의 입원할 때의 나이가 대부 분 출생 후 24 시간 이내였음을 확인할 수 있었다. 그리고 이러한 빠 른호흡은 출생 후 72 시간 이내에 호전되는 비율이 $72.1 \%$ 로 최소 3 일 이내에는 좋아지는 소견을 보이며, 대부분 7일 이내에 호전되었음 을 알 수 있었다. 또한, 60 회/분 이상의 빠른호흡도 $74.4 \%$ 에서 관찰 되었듯이 다른 연구들에서와 같이 가장 흔한 호흡 증상이었음을 알 수 있었다 ${ }^{5,15)}$.

미숙아가 신생아 호흡곤란 증후군과 신생아 일과성 빠른호흡의 위험인자로 본 연구에서도 37 주 미만 미숙아 비율이 폐렴군에서 $13 \%$ (2/15) 차지하는 것에 비해 신생아 호흡곤란 증후군 35\% (7/20) 와 신생아 일과성 빠른호흡 35\% (18/51)로 높게 보이는 것을 알 수 있었다. 그리고 미숙아의 경우 신생아 호흡곤란 증후군과 신생아 일 과성 빠른호흡을 동시에 가질 수 있으나 신생아 호흡곤란 증후군은 신생아 일과성 빠른호흡과 다르게 입원 당시 $\mathrm{pH}$ 가 $7.27 \pm 0.10$, 산소

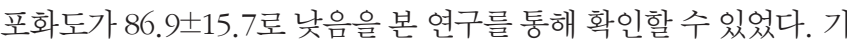
계적 인공호흡기 치료에 낮은 배꼽 동맥 $\mathrm{pH}$ 가 의미 있는 위험인자 로 관련이 있다고 한 것처럼 ${ }^{12)}$ 본 연구에서 총 기계적 환기 치료가 길었던 신생아 호흡곤란 증후군과 낮은 $\mathrm{pH}$ 와 관련성이 있음을 확인 하였다. 흥부 방사선 사진 검사에서는 신생아 호흡곤란 증후군과 폐 렴에서는 특징적인 방사선 이상 소견이 많이 관찰되었으나 신생아 일과성 빠른 호흡 환자들은 특징적인 소견을 보이지 않는 경우도 많 았음을 확인하였다.

주로 조기 양막 파수, 미숙아, 모체 감염 등이 위험인자가 되며 대 표적으로 바이러스 및 세균이 폐렴의 원인이 된다 ${ }^{13,14}$. 원인균과 병 원성에 따라 그 예후가 다양하여 감염이 의심되는 경우에 빠른 처치 를 하면 사망률을 줄일 수 있으므로 ${ }^{12,14)}$ 본 연구에서도 균 동정이 되
지 않는다 해도 아이에게서 혈액 배양을 하는 것이 치료에 유용하므 로 $^{2)}$ 시행하였다. 그러나 혈액에서 균이 동정 되거나 바이러스가 관 찰된 경우는 없었다. 그럼에도 본 연구에서는 폐렴 환자들에서 첫 hsCRP가 의미 있게 상승되어 있었으므로 hsCRP 결과를 통해 항생 제 투여를 하면서 감별이 확실히 이루어질 때까지 경과를 볼 수 있을 것으로 여겨진다. 또한, 신생아 일과성 빠른호흡은 항생제 치료가 필요 없는 것과 같이 ${ }^{4)}$ 본 연구에서도 신생아 일과성 빠른호흡 환자 들은 입원 당시 hsCRP와 추적한 최대 hsCRP 수치도 정상 범위 안에 있었다. 그러므로 hsCRP를 통해서도 호흡곤란을 일으키는 원인 질 환을 감별할 때에 도구로 사용할 수 있을 것이라 여겨진다. 그리고 신생아 호흡곤란 증후군에서는 소변량이 생후 첫날 적을 수 있으므 로 수액의 투여 및 배출량을 잘 확인해야 할 것이다.

출생 후 호흡곤란을 보이며 전원 온 재태 기간 34 주 이상의 환자 들에서 빠른호흡 증상이 가장 많이 관찰되었다. 신생아 일과성 빠른 호흡, 신생아 호흡곤란 증후군, 그리고 폐렴 환자들이 발생 초기에 비슷한 호흡 증상으로 시작하여 일찍 감별할 수 없으므로 환자의 출 생 체중, 입원할 때 $\mathrm{pH}$ 와 base excess, 무호흡 증상 여부, 입원 첫날 소변량, 그리고 hsCRP 등으로 호흡곤란의 진행 및 악화 여부와 초 기 항생제 치료를 결정하면서 고려해 볼 수 있는 소견이라고 여겨진 다. 하지만 본 연구에서는 원인에 따른 이유에 신생아 가사, 패혈증, 공기누출증후군, 태변 흡인증후군과 같은 것 ${ }^{1)}$ 이 배제되어 있고 단 일 기관에 입원한 5년간의 입원 환자에 대해서 적은 수의 대상자로 비교 분석하였기에 결론을 일반화하기에 충분하지 않다. 또한, 전원 된 환자들만 대상으로 하였기에 산전 스테로이드의 투여 여부 및 조 기 양막 파수와 같은 위험인자에 대한 정보가 정확하지 않으므로 더 큰 연구가 필요하리라 생각된다.

\section{REFERENCES}

1) Parkash A, Haider N, Khoso ZA, Shaikh AS. Frequency, causes and outcome of neonates with respiratory distress admitted to Neonatal Intensive Care Unit, National Institute of Child Health, Karachi. J Pak Med Assoc 2015;65:771-5.

2) Gallacher DJ, Hart K, Kotecha S. Common respiratory conditions of the newborn. Breathe (Sheff) 2016;12:30-42.

3) Edwards MO, Kotecha SJ, Kotecha S. Respiratory distress of the term newborn infant. Paediatr Respir Rev 2013;14:29-36.

4) Hermansen CL, Lorah KN. Respiratory distress in the newborn. Am Fam Physician 2007;76:987-94.

5) Agrawal V, David RJ, Harris VJ. Classification of acute respiratory disorders of all newborns in a tertiary care center. J Natl Med Assoc 2003;95:585-95.

6) Consortium on Safe Labor, Hibbard JU, Wilkins I, Sun L, Gregory K, Haberman S, et al. Respiratory morbidity in late preterm 
births. JAMA 2010;304:419-25.

7) Warren JB, Anderson JM. Newborn respiratory disorders. Pediatr Rev 2010;31:487-95.

8) Sengupta S, Carrion V, Shelton J, Wynn RJ, Ryan RM, Singhal K, et al. Adverse neonatal outcomes associated with early-term birth. JAMA Pediatr 2013;167:1053-9.

9) Alderdice F, McCall E, Bailie C, Craig S, Dornan J, McMillen $\mathrm{R}$, et al. Admission to neonatal intensive care with respiratory morbidity following 'term' elective caesarean section. Ir Med J 2005;98:170-2.

10) Donaldsson SF, Dagbjartsson A, Bergsteinsson H, Hardardottir $\mathrm{H}$, Haraldsson A, Thorkelsson T. Respiratory dysfunction in infants born by elective cesarean section without labor. Laeknabladid 2007;93:675-9.
11) Derbent A, Tatli MM, Duran M, Tonbul A, Kafali H, Akyol M, et al. Transient tachypnea of the newborn: effects of labor and delivery type in term and preterm pregnancies. Arch Gynecol Obstet 2011;283:947-51.

12) Bak SY, Shin YH, Jeon JH, Park KH, Kang JH, Cha DH, et al. Prognostic factors for treatment outcomes in transient tachypnea of the newborn. Pediatr Int 2012;54:875-80.

13) Reuter S, Moser C, Baack M. Respiratory distress in the newborn. Pediatr Rev 2014;35:417-28.

14) Nissen MD. Congenital and neonatal pneumonia. Paediatr Respir Rev 2007;8:195-203.

15) Ersch J, Roth-Kleiner M, Baeckert P, Bucher HU. Increasing incidence of respiratory distress in neonates. Acta Paediatr 2007; 96:1577-81. 